\title{
SAJEST
}

http://dx.doi.org/10.4314/sajest.v4i1.39815

Original Article

国Open Access

Received: June 2014 / Accepted: 1 August 2016

Published online: June 2017

\section{Challenges faced in controlling wildland fires in Mazowe A1 resettlement farming areas of Zimbabwe}

George Nyamadzawo $^{1}$, Stenly Mapurazi ${ }^{1}$, Praise Mukutirwa ${ }^{1}$, Maxwell Mupotsa $^{1}$

\begin{abstract}
Wildland fires pose a big threat to both flora and fauna. In Zimbabwe an estimated 1 million hectares (ha) are burnt annually. The present study uses multiple sources of information including review of published literature, reports, field observations, questionnaires and interviews to investigate the challenges faced in controlling wildland fires in A1 resettlement farming areas of Zimbabwe. Two sites, ward 24 and 31 in Mazowe District were used as case studies to compile responses from 400 households. The results of the study indicated that issues of education, experience and lack of information in wildland fire management played a role in wildland fire management. In ward $24.6 \%$ never attended school, while $30 \%, 48 \%$ and $8 \%$ had reached primary education, secondary education and tertiary education respectively. In ward 31, the highest level of education of the respondents was $8 \%, 58 \%$ and $34 \%$ for primary level, secondary level, and tertiary education respectively. The predominant challenge was lack of experience in fire control as
\end{abstract}

Corresponding Author :

George Nyamadzawo*, Stenly Mapurazi, Praise Mukutirwa, Maxwell Mupotsa Department of Environmental Science,Bindura University of Science Education, P. Bag 1020, Bindura, Zimbabwe. E-mail: gnyama@yahoo.com
$52 \%$ of the respondents had never been involved in fire suppression. In addition, lack of information was highlighted as a major cause of wildland fires, as only $35 \%$ of respondents had attended fire awareness campaigns. The other challenges included; lack of proper fire fighting equipment, poor volunteerism and poor implementation of policies and regulations. It was concluded that multiple challenges exist in managing wildland fires, and hence more emphasis should be placed in training and equipping communities with fire management skills and provision of fire fighting equipment. A multi-sectoral approach is also recommended for implementation and enforcement of fire management regulations in the resettlement farming areas.

Keywords: Fires, resettlement farming areas, fire management, Mazowe District, sectorial approach.

\section{INTRODUCTION}

Wildland fires over the years have continued to ravage ecosystems causing damage to the environment. In most farming areas in Zimbabwe, cropped land, grasslands and pasturelands have been destroyed during the dry season causing 
shortage of herbage material and hence low 2007). Wildland fires have destroyed property, caused loss of human life and exerted unquantifiable damage to the ecosystems throughout Zimbabwe (Ndangana, 2006). Since wildland fires continue to play a role in environmental degradation, it is therefore important to improve fire management especially in rural environments where communities live close to bush or forested areas and where livelihoods are hinged on natural resources (Chigurah et al., 2010). There are thought-provoking statistics about wildlands fires and their effects. According to Roberts and Wooster (2008), fires in the African continent were estimated to account for between $30-50 \%$ of the total annual biomass burned globally over the past eight years. In spite of efforts by various environmental organizations to curb fire incidences, wildland fires continue to be a major threat to agricultural activities. This is signified by an increase in hectarage lost, for example, in Zimbabwe, the area burnt increased from 713770 hectares (ha) in 2011 to 1.5 million ha in 2015 (EMA, 2012). These statistics calls for greater attention to deal with wild land fires and also to look at possible mitigating factors in dealing with this menace.

A large percentage of people living in A1 resettlement farming areas and rural communities in Zimbabwe, heavily depend on agriculture and forest products for their livelihoods (Ndangana, 2006). Fire incidences is one of the major challenges that the resettlement farmers in $\mathrm{A} 1$ villagised schemes especially when they hunt for small game animals such as pigs and mice. This practice removes vegetation cover and its camouflaging effect and it becomes very easy to productivity in livestock production (Svotwa et al., catch the wild animals. Resultantly, these wild land fires have destroyed ecosystem goods and services that the rural people derive from forests to sustain their livelihoods (Chigurah et al., 2010).

Several factors have been responsible for the occurrence of the wildland fires. The use of fires for land preparation by resettled farmers has been pointed out as one of the major cause of wildland fires (Svotwa et al., 2007; Phiri et al., 2011). Other causes of wildland fires include smoking out beehives, charcoal preparation, gold panning, and cooking (Chimatira et al., 2016). In the Southern African region some fires are started deliberately during the early winter to promote a green flush for their animals and by hunters clearing vegetation to catch their prey more easily (Nkomo et al., 2009; EMA, 2011), by people creating firebreaks around their homesteads or seeking to improve visibility, or by children playing with fires.

In Zimbabwe, cases of arson where employees are disgruntled over non-payment of salaries or low salaries have been reported in large-scale forested areas (Nyamadzawo et al., 2013). Ownership or land tenure disputes have been reported as the underlying causes of arson fires (FAO, 2007). Wildland fires can also be a result of roadside fires for warming especially during the cold dry winters, and can also start from lit cigarettes thrown out from moving vehicles (EMA, 2011). EMA (2011) reported that $60 \%$ of all fires occurred within 500 $\mathrm{m}$ from major highways as a result of roadside fires and throwing out of lit cigarettes and road accidents where vehicles catch fire. Some infrequent accidents such as by locomotives derailment and electrical faults from power lines have also been reported to cause wildland fires. 
Wildland fires can be controlled through several ways which include education (improved community awareness) and strategies such as fire guard construction. The government of Zimbabwe through the Environmental Management Agency (EMA) has been educating the public on the dangers of uncontrolled wildland fires through printed literature, television and radio programmes. Several Acts of Parliament aimed at preventing fires such as the Environmental Management Agency CAP 20:27 of 2007, Parks and Wildlife Act CAP 20:14 of 1996, Forest Act CAP 19:05 of 1996 and the traditional leaders ACT of 1998 have also been enacted though the problem of wildland fires still exists. In spite of these efforts, both the ecosystem and people's lives and property remain in danger from wildland fires. Fire management remains a major challenge in wards 24 and 31 . Therefore, the objective of this study was to investigate the challenges that are faced in controlling wildland fires in A1 resettlement farming areas of Zimbabwe, using two in Mazowe as case studies.

\section{MATERIALS AND METHODS}

Study Site

The study was carried out in two wards, wards 24 and 31 of Mazowe district located in Mashonaland Central Province approximately $40 \mathrm{~km}$ North of Harare. The study area is characterized by, small and large scale commercial farms under both A1 and A2 land resettlement model. For this study, only A1 households were considered as wild land fire incidences are highly pronounced in the area. Mazowe receives an average of 750-1000 mm of rainfall per year and average daily temperatures of
$15 \mathrm{oC}$ and $30 \mathrm{oC}$ in summer. The dominant soils which are moderately deep to deep reddish brown Ferrallitic soils formed from mafic rocks. The vegetation consists of miombo woodlands and scattered grasses. The dominant grass is mainly Hyparrhenia filipendula and forest is dominated with by Brachystegia tree species. Crops grown include maize, tobacco, wheat and soya beans and citrus farming. Figure 1 shows the map of Mazowe district.

\section{Sampling}

Two wards were selected namely ward 24 and 31 . Theses wards were purposefully chosen as the prevalence of wildland fires has been high, hence there was a need to conduct an in-depth study using two case studies. In ward 24 of Mazowe Rural District, 250 households were randomly selected to whilst in ward 31,150 households were also randomly selected using computerised random numbers. All in all the total number of households interviewed reached 400. These were further stratified in equal numbers of males and females to avoid bias in the responses.

\section{Data collection}

Multiple data sources including review of published literature, reports, field observations, questionnaires and interviews were used to collect data. The questionnaires used had both closed and open format questions. Open format questions were introduced to allow respondents to give their individual opinions. Interviews were conducted with key informants (headmen, AGRITEX and EMA officers, ZRP representatives, elders and teachers). Additional data were also collected from 


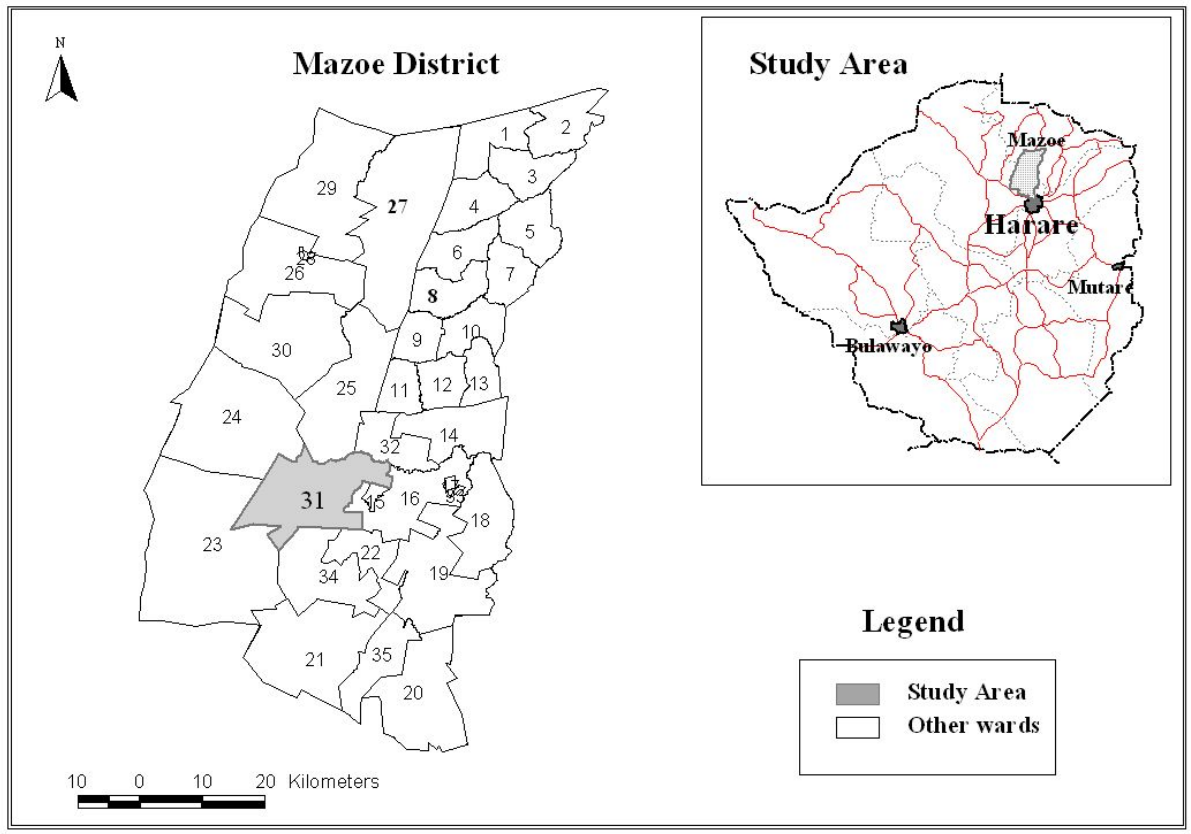

Figure 1. Map of ward 31 and the neibhouring ward 24 of Mazowe District, Zimbabwe.

\section{RESULTS}

\section{Education status of respondents}

In ward $24.6 \%$ never attended school, while $30 \%$, $48 \%$ and $8 \%$ had reached primary education, secondary education and tertiary education respectively, whereas in ward 31 , the highest level of education of the respondents was $8 \%, 58 \%$ and $34 \%$ for primary level, secondary level, and tertiary education respectively. The respondents' view on fire suppression depended on the level of education. All the respondents who attained primary level of education said they did not worry about suppression of wildland fires, while $91 \%$ and $100 \%$ of those who attained secondary and tertiary level all agreed to the need for fire suppression.

\section{Causes of wild land fires}

The major causes of wildland fires were identified as of anthropogenic origin in both ward 24 and 31 . The major cause of wildland fires was land clearing which accounted for $50 \%$ and $35.5 \%$ of the fires for ward 24 and 31 respectively. Hunting resulted in the outbreak of about $20 \%$ and $8 \%$ of the wildland fires in ward 24 and 31 respectively. The deliberate lighting of wildland fires for no apparent reason reported by $18 \%$ respondents in ward 24 and $12.5 \%$ in ward 31 . Other causes of wildland fires were cited as, children playing with fires $(10 \%)$, smoking $(2 \%)$, panning $(3.3 \%)$ and bee smoking $(2.6 \%)$. There was a great variation of perceptions on major causes of wildland fires in the area and the views depended on whether the person was involved in fire suppression or not, years of 
experiencing wildland fires, and whether there was a fire fighting team in the area.

\section{Reasons for fighting wildland fires}

Several reasons were given on why wildland fires should be suppressed. Twenty five percent (25\%) of the respondents suggested that wildland fires should be suppressed to avoid the destruction of property and livestock, 23\% suggested that wildland fires should be suppressed to prevent damage to crops and livestock, and $23 \%$ suggested that they should be prevented to avoid the death and injury of people. Thirteen percent of the respondents suggested that fires should be prevented to avoid damage to property while $7 \%$ suggested that fires should be prevented to avoid damage to the environment and the ecosystem (Figure 2). A total of $66 \%$ of respondents, who never own any livestock agreed that wildlands fire should be suppressed, compared to $100 \%$ of livestock owners who agreed to fire suppression.

\section{Gender and fire suppression}

The majority $(72 \%)$ of the women respondents agreed that fire suppression should be carried out, while $28 \%$ were indifferent to fire suppression. A total of $92 \%$ of men were agreeable to fire suppression. Only $11 \%$ of the youth took part in the extinguishing of wildland fires. Most of the youth would light fires and ignore them as they spread.

\section{Challenges in controlling wildland fires}

Several reasons were given as challenges faced in controlling wildland fires. The most common was that there was lack of experience in fire control as $52 \%$ of the respondents had never been involved in fire suppression, while only $26 \%$ had been involved in fire suppression. The majority of those who had not been involved in wildland fire suppression were the youth and women. The results showed that people that had no fire fighting teams in their villages and not been involved in firefighting are 2.6 times more likely to have a low response to a fire incident and to be involved in fire suppression. 


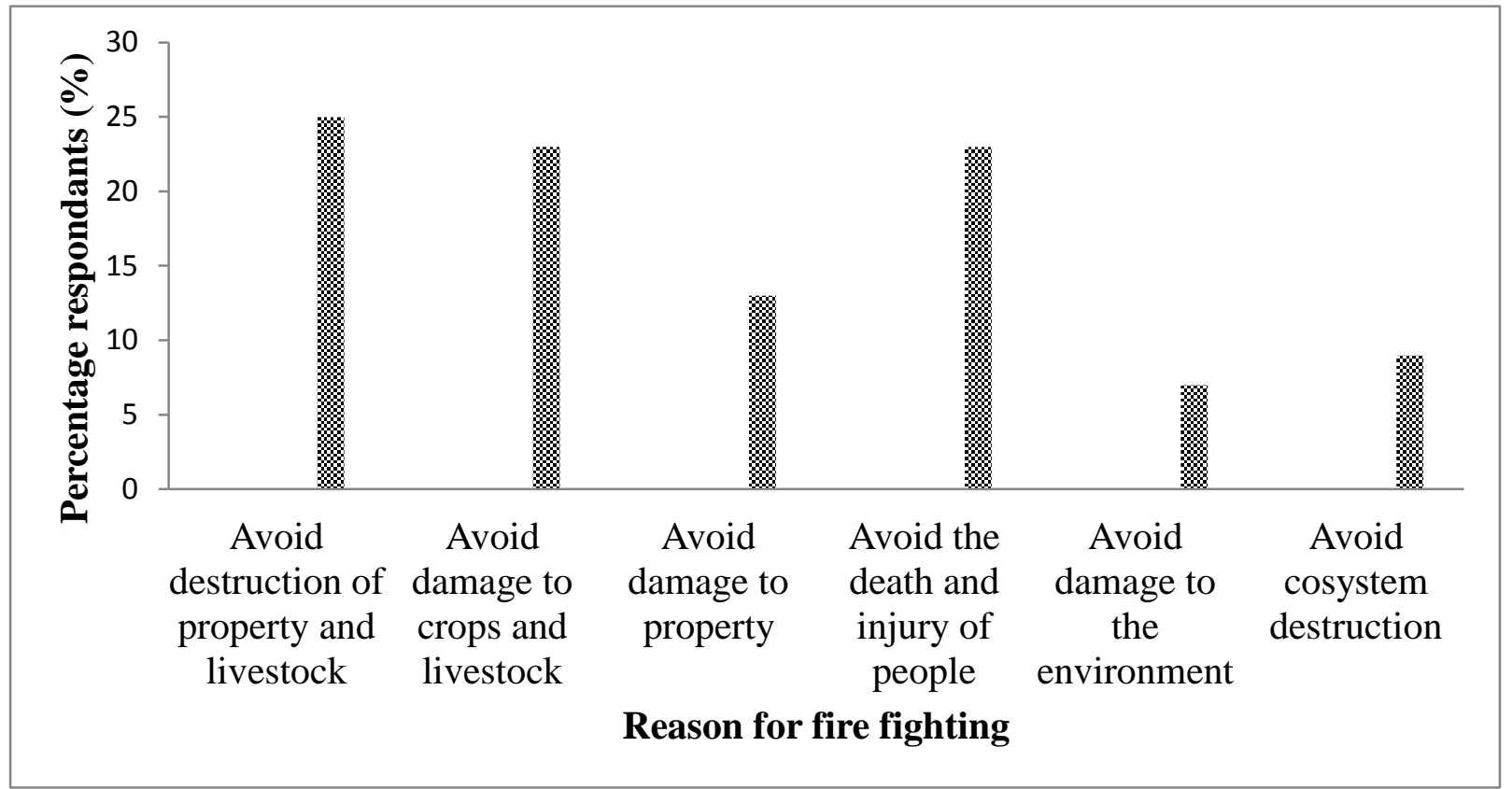

Figure 2. Reasons for fighting wildland fires

The other challenge that was observed was the lack of cooperation among community members. The youth did not put much value in environmental conservation in the area and this had a negative effect on their response to wildland fires. Adults were the ones who tended to respond to fires quickly and showed concern at the destruction caused by the fires. The youth were blamed for igniting most of the fires in the area during hunting expeditions.

The study found out that there were wildland fire awareness campaigns that were conducted in the study area towards the fire season. Only $35 \%$ of the respondents stated that they had attended wildland fires campaigns. Education (awareness) received by respondents about wildland fires usually came from EMA, Forestry Commission officers and local leadership towards the fire seasons in addition to programmes on radio and television but these campaigns are few. Most respondents also cited the lack of proper firefighting equipment as another challenge to fighting wildland fires. Some respondents cited the lack of resources to construct fireguards as another challenge. Another challenge was poor fire detection since most fires occurred at night when most of people are asleep.

Lack of knowledge on firefighting legislation was seen as one of the most reported challenges in dealing with wild land fires. Most respondents did not know that there was legislation that was put in place to guard against wildland fires. Approximately $60 \%$ of the respondents stated that they did not know about any legislation on wildland fires. One respondent on being asked whether they knew that they were supposed to inform their neighbor before starting a fire on their 
premises stated that: "Why is it my neighbors' business to inform them of what I do in my farm?"

The local leadership play an important role also in dealing with the issues of wildland fires. However, concern was raised on the diminishing role and annexation of the power of the traditional leadership by the government. The role played by indigenous knowledge systems (IKS) has been shown to be important since it encourages a grassroots approach on wildland fire management. The research findings revealed that the headman and chiefs also conducted awareness campaigns and IKS in order to inform people on the dangers of wildland fires.

\section{DISCUSSION}

The level of education had a bearing on response to fire fighting in A1 resettlement area of Mazowe district. All the respondents who had not attained primary education level did not attach much importance to controlling wildland fires. Among those who had attained secondary education, some were conversant of the dangers of wildland fires but interestingly, they did not put the knowledge into practice. However, those who had attained tertiary education showed much concern about the wildland fires and did what was in their ability to conserve their environment by adopting fire preventive measures. On the same note, the respondents who attended environmental education and awareness meetings and campaigns had higher levels of responses than those who never attended these meetings. These were found to have better appreciation of environmental issues. It is during these meetings and campaigns that issues to do with veld fires including skills on how to fight veld fires are discussed and also imparted to the community.

The youth did not put much value in fire suppression were blamed for igniting most of the fires in the area during hunting expeditions. This is probably because they are the most active members of the society who normally engage in hunting activities. The spread of the fires would then depend on the success in catching the prey. If the hunted animals encroach onto another forest area then the hunters will light fires in the new area. This explains why fires sometimes jump fire guards erected. Sturtevant and Cleland (2007) revealed that the likelihood of fire to starts is primarily influenced by human activity whereas biophysical factors determine whether those fire starts become large fires.

Women were more concerned and responded by trying to extinguish fires near their homes. Ryan and Wamsley (2008) and Lim et al., (2009) reported that males are less concerned about the risks of fire near homes. This is probably because women are usually at home than man who are normally more mobile in the forest hunting. It is more likely that man who like hunting are the ones who cause much of the fires which then spread from the wild towards homes especially when economic conditions are not very favourable to create employment for them. In Russia, it was discovered that the political and economic crises were the main underlying causes of recent largescale fires (IUCN/WWF, 2000).

Most of the A1 farms are densely populated as compared to A2 farming areas and land is often underutilised and this causes increased fuel load. Studies around the globe affirms that population 
density is positively related to wildfire ignitions (Cardille et al., 2001). Furthermore, land clearing and hunting were cited as the major causes of wildland fires. Most A1 resettlement farming areas of Zimbabwe have limited resources and equipment to clear and prepare the land using mechanical methods; hence farmers frequently use fires for land preparation (Nyamadzawo et al., 2013). Besides land clearance, households in Mazowe use fire in harvesting wild honey and hunting wild pigs. This concurs with the Secretariat of the Convention on Biological Diversity (2001) that wildland fires in the tropics are due to land clearing with fire, accidental or escaped fire, and fires connected with resource extraction.

In a study in Cashel Valley, Zimbabwe, $60 \%$ of the respondents agreed that land clearing was the major cause of fires in the area (Nkomo et al., 2009). Hunting is another major cause of wildland fires in the area mainly because the hunting season coincides with the dry season when the fuel load is high in addition to hot and windy conditions which enhance the initiation and spread of wildland fires (Kilahama, 2011). These findings are also supported by Panzer and Schwartz, (2000); Svotwa et al. (2007) and Nkomo et al., (2009). Most of the causes of wildland fires were human caused, and the same was reported from 10 year study in the USA with recorded $88 \%$ of the fires as human caused (NFA, 2001).

Several reasons were given to justify the need to suppress wildland fires. The main reasons were to prevent economic damage to crops, livestock and the environment. In addition, the protection of human life was also highlighted as a major reason to fight wildland fires. In previous fires seasons, human life has been lost due to wildland fires. A total of $10,25,5$ and 5 people lost their lives in 2009, 2010, 2011, and 2012 respectively due to wildland fires (Nyamadzawo et al., 2013). The results showed that the majority of women are more concerned about the effects wildland fires than men since most of their economic activities such as gardening and cultivation are more susceptible to fire damage.

Non-livestock owners were less concerned about of fire suppression and control. The main reason was that livestock owners are more concerned about potential loss of on pasturelands for their livestock. This is in agreement with Nkomo et al., (2009) who noted that wildland fires destroy pastures which are a source of feed for livestock. However, some farmers who owned livestock asserted that they would not fight wildland fires as long as their crops and property are not threatened. They argued that wildland fires assist in tick-control and to ensure the regeneration of good pasture grass. They only lamented the timing of burning since it has to be done just before the onset of the rain season to allow the grass to quickly regenerate and provide feed to livestock.

The other challenges faced in controlling wildland fires included the lack of firefighting equipment such a beaters, water bowsers and knapsack sprayers. This has an effect on response levels. Well-equipped members of the community had higher levels of responses wanting to put their equipment to full use. They had security against fires as a result of firefighting equipment. Some respondents were interested in wildland fire control but would end up not doing so because of lack of firefighting equipment. Without proper firefighting equipment it becomes difficult to control wildland 
fires. The lack of financial resources hampers the procurement of firefighting equipment. This is obvious in A1 farms where the majority of the households are living in poverty hence acquisition of firefighting equipment could be a major challenge.

Another challenge that was faced in fighting wildland fires was the lack of knowledge and experience on wildland fire control. People with a fire fighting team in their area had knowledge of the major causes of fire than those who did not have a fire fighting team due to ignorance and reluctance to be involved in fire suppression. People who were once involved in suppression had knowledge on the most prevalent causes of wildland fires (Gan et al., 2015). Choga and Nyamadzawo (2016) (unpublished) in a study in Makoni reported that up to $70 \%$ of resettled people came from urban areas, $15 \%$ from nearby villages and $15 \%$ from rural areas. People with no fire that it was a crime not to take part in the suppression of wildland fire.

Ignorance and lack of concern about impact of fires was also a challenge in controlling wildland fires. If there is no one taking responsibility over the fire then even though it affects everybody, no one would take the initiative to mobilise others. The villagers revealed that they have a NIMBY (Not in my backyard) syndrome that entails that they are not worried with fires that do not threaten their property directly even though they derive benefits from the environment which is prone to fire damage. The community's negative attitude towards fires was illustrated by the fact that of the 46 fires that were recorded in 2013 in ward 24, only 5 were extinguished on time. The people also took long to respond to fire outbreaks such that the fighting teams in their area and who have never been involved in fire suppression are less likely to respond quickly to a fire incident and be involved in fire suppression compared to those with firefighting teams and experience (Gan et al., 2015). McCaffrey (2008) and Toledo et al., (2013) reported that the land owner's knowledge towards prescribed burning and suppression of wildland fires is associated with previous experiences.

There was blame game between the structures of society in ensuring that policies and legislation on wildland fires are put into practice. For example, the local leaders stated that they are not adequately empowered by the other institutions to deal with those caught committing crimes involving wildland fires. The Environmental Management Act (20:27) has contributed to a reduction in the occurrence of wildland fires since the legislation acts as a deterrent to would-be offenders. However, some respondents also indicated that they were not aware fires rapidly spread to long grass and became dangerous and difficult to extinguish. As such wildland fires of high intensity are generally more difficult, and costly to fight small fires (Daniel et al., 2007).

Whilst respondents appraised the critical role of local leadership in dealing with the issues of wildland fires through raising awareness and promoting the upholding of indigenous knowledge systems, there has been a notable level of resistance from other groups mainly the farm workers left in the compounds by former farm owners and newly resettled farmers who moved in from other areas and do not uphold the local cultural and traditional conservation ideologies. Local leaders were also concerned about new comers who were not following the norms and values of the area, hence making it difficult to control wildland fires. The 
lack of cooperation amongst community members on the aspect of wildland fires was a challenge.

\section{CONCLUSIONS}

Education was a key factor in determining the level of involvement in wildland fire issues. Response to wildland fires, increased as the level of education increased. Wildland fires were caused by several activities but the most common cause were farmers who use fires for land preparation and hunting. The challenges faced in controlling wildland fires included inadequate education or lack of it and lack experience on wildland fires and ignorance of legislation on wildland fires which is a result of inadequate education of community members. There is also lack of fire-fighting equipment, and lack of resources and finances to purchase the required equipment. Lack of unity and oneness amongst the community members is another challenge to reducing wildland fire in the community. The annexation of the powers of local leaders also poses a challenge to fighting wildland fires as they are failing to punish effectively perpetrators of wildland fires Regardless of the numerous challenges faced in fighting wildland fires in Mazowe, wildland fires should be controlled at any cost for the conservation of the environment. It was concluded that multiple challenges exist in managing wildland fires, and it is recommended that more emphasis should be placed in preventive policy measures such as training and equipping communities with fire management skills and provision of firefighting equipment. A multi-sectoral approach is also recommended for implementation and enforcement of fire management regulations in the A1 resettlement farming areas.

\section{Acknowledgements}

We are also grateful to the ward 24 and 31 communities in Mazowe for allowing us to carry out this work in their area.

\section{References}

Cardille, J.A., Ventura, S.J., Turner, M.G. 2001.

Environmental and social factors

influencing wildfires in the Upper Midwest, USA.

Ecological Applications 11(1): 111-127.

Chigurah, C., Stevie, J. 2010. Analysis of Veld Fire Incidents in Makoni and Chimanimani Districts of Zimbabwe Using GIS and Remote Sensing and Public Domain Data. Journal of Sustainable Development in Africa 2: 7.

Chinamatira, L., Mtetwa, S., Nyamadzawo, G. 2016. Causes of wildland fires, associated socio-economic impacts and challenges with policing, in Chakari resettlement area, Kadoma, Zimbabwe Fire Science Reviews 5: 1. doi:10.1186/s40038-016-0010-5

Choga, D., Nyamadzawo, G. 2016. Causes Of Wildland Fires And Factors That Influence Knowledge Of Wildland Fires Management At Crofton Village, Makoni District of Zimbabwe. Working paper.

Daniel T.C., Carroll, M.S., Moseley, C., Raish. C. (Eds). 2007. People, Fire, and Forests: a 
Synthesis of Wildfire Social Science. (Oregon State University Press: Corvallis, OR)

EMA. 2011. Environmental Management Authority (EMA) fire assessment report. EMA, Harare, Available from: ttp://www.ema.co.zw/index.php/component/conten t/article/1-

latest-news].

EMA. 2012. Environmental Management Authority (EMA) of Zimbabwe. EMA, Harare, Available from:

[http://www.ema.co.zw/index.php/component/cont ent/article/1-latest-news]FAO , (2007), “ Fire management-global assessment", A thematic study prepared in the framework of the Global Forest Resources Assessment 2005, FAO Forestry Paper 151, Rome.

FAO. 2007. Fire Management - Global Assessment 2006. FAO Forestry Paper 151. Rome, Italy.

Gan, J., Jarrett, A., Johnson Gaither, C. 2015. Landowner response to wildfire risk: Adaptation, mitigation or doing Nothing. Journal of Environmental Management 159: 186-191.

IUCN/WWF. 2000. Global Review of Forest Fires. The World Conservation Union (IUCN) and Worldwide Fund for Nature (WWF), Gland Switzerland. 64 pp.

Kilahama, F. 2011. Integrated Fire Management and Reduced Emissions through Deforestation and Degradation programme (REDDPLUS): In: Proceedings of the 5th International Wildland Fire Conference, Suncity, South Africa, (9-13 May
2011) p. 19. Available at; http://www.fao.org/docrep/014/am663e/am663e00. pdf. Accessed 23/4/2016.

Lim, S.H., Bowker, J.M., Johnson, C.Y., and Cordell, H.K. 2009. Perspectives on prescribed fire in the south, does ethnicity matter. Southern Journal of Applied Forestry 33(1): 17-23.

McCaffrey, 2008. The public and wildland fire management: Social science findings for managers).Newtown Square, PA: U.S. Department of Agriculture, Forest Service, and Northern Research (pp. 14). NFA (2001). US fire Administration Topical Research Series. Volume 1(issue3). Available at; http://nfa.usfa.dhs.gov/downloads/pdf/statistics/v1i 3-508.pdf. Accessed 23/4/2016.

Ndangana, J. 2006. Fire Damage, Natural Resource Department, Natural Resources Board (NRB)

Harare, Zimbabwe.

Nkomo, G.V., Sassi, M. 2009. Impact of veld fires on land on resettlement farmers in Cashel Valley Cashel Valley in Zimbabwe, Natural Resources, Agricultural Development and Food security, International Research Network 9 (2): 1-17.

Nyamadzawo, G., Kanda, A., Kuhlande. A., Masona, C. 2013. Understanding the causes, socioeconomic, environmental impacts and Management of Veld fires in tropical Zimbabwe. Fire Science Reviews 2: 2.

Panzer, R., Schwartz, M. 2000. Effects of management burning on prairie insect species 
Richness within a system of small highly fragmented reserves. Biological Conservation 96: 363-369.

Phiri, M., Zingwena, S., Mahamba, S.M. 2011. Community-based fire management; experiences from the FAO funded project in the provinces of Manicaland and Matebeleland North, Zimbabwe. In: FAO, Integrated fire approach: From global monitoring to natural fire management, Fire management working paper FM/27/E. FAO, Rome, pp 51-60. doi:10.1071/WF03015

Roberts C.J., Wooster, M.J. 2008. Fire detection and fire characterization over Africa using Meteosat Seviri. IEEE Transactions on Geoscience and Remote Sensing, 46 (2008), pp. $1200-1218$

Ryan, R.L., Wamsley, M.B. 2008. Public perceptions of wildfire risk and forest management in the central pine barrens of long island (USA). The Australasian Journal of Disaster and Trauma Studies 2: 1-16.

Svotwa, E., Ndangana, F., Manyanhire, O., Mushava I. 2007. Veld Fire Risk Assessment and Community Based Control Strategy in Norton Farming Area of Zimbabwe. Journal of Sustainable Development in Africa 9(2) 15205509.

Toledo, D. et al., 2013. Social and ecological factors influencing attitudes toward the application of high-intensity prescribed burns to restore fire adapted grassland ecosystems. Journal of Ecology and Society 18(4): 9.
Secretariat of the Convention on Biological Diversity, 2001. Impacts of human-caused fires on biodiversity and ecosystem functioning, and their causes in tropical, temperate and boreal forest biomes. Montreal, SCBD, Technical Series no. 5, 42p.

Sturtevant, B.R., Cleland, D.T. 2007. Human and biophysical factors influencing modern fire disturbance in northern Wisconsin, International Journal of Wildland Fire 16: 398-413.

Zimstat. 2012.

http://www.zimstat.co.zw/sites/default/files/img/pu blications/Census/CensusResults2012/Mash_Centr al.pdf 